\title{
Pre-frailty in the elderly and the driver license test for motor vehicles
}

\author{
Pré-fragilidade em idosos e a habilitação para direção de veículos automotores
}

Maria Helena Lenardt ${ }^{1}$, Susanne Betiolli ${ }^{1}$, Letícia Marie Sakai ${ }^{1}$, Nathalia Hammerschmidt Kolb Carneiro ${ }^{1}$, Maria Angélica Binotto ${ }^{1}$, Dayana Cristina Moraes ${ }^{1}$

Objective: to investigate the association between the condition of physical pre-frailty in elderly people and the final results of the driver license test for motor vehicles. Methods: cross-sectional study carried out with 347 elderly who underwent driver license tests. A questionnaire and tests were applied, and information on the result of the driver license test was collected. A descriptive statistical analysis and a non-parametric test were performed. Results: $163(47.0 \%)$ were found to be pre-frail, 71 (43.6\%) had reduced hand grip strength, 65 (39.9\%) had reduced level of physical activity and 62 (38.0\%), reduced gait speed. The result of the driver test indicated $115(70.6 \%)$ pre-frail elderly to be able to drive with restriction. Pre-frailty was not associated with the results of the driver license test $(\mathrm{p}=0.744)$. Conclusion: although the pre-frail condition was frequent, there was no significant association with the result of the driver test.

Descriptors: Frail Elderly; Geriatric Nursing; Physical Fitness; Automobile Driver Examination; Automobile Driving.

Objetivo: investigar a associação entre a condição de pré-fragilidade física e os resultados finais da habilitação de idosos para dirigir veículos automotores. Métodos: estudo transversal realizado com 347 idosos submetidos aos exames de habilitação. Aplicou-se questionário estruturado, testes para avaliação da fragilidade física e coletadas informações do resultado da habilitação. Foi realizada análise estatística descritiva e teste não paramétrico. Resultados: encontraram-se 163 (47,0\%) pré-frágeis, 71 (43,6\%) deles possuíam força de preensão manual diminuída, 65 (39,9\%) redução do nível de atividade física e 62 (38,0\%) velocidade da marcha reduzida. 0 resultado do exame indicou $115(70,6 \%)$ pré-frágeis aptos com restrição. A pré-fragilidade não se associou aos resultados da habilitação veicular $(\mathrm{p}=0,744)$. Conclusão: embora a condição de pré-fragilidade tenha se mostrado elevada entre os idosos submetidos ao exame de aptidão física e mental para a habilitação veicular, não houve associação significativa entre essa classificação de fragilidade e o resultado da habilitação veicular.

Descritores: Idoso Fragilizado; Enfermagem Geriátrica; Aptidão Física; Exame para Habilitação de Motoristas; Condução de Veículo.

11Universidade Federal do Paraná. Curitiba, PR, Brazil.

Corresponding author: Letícia Marie Sakai

Universidade Federal do Paraná. Av. Lothário Meissner, 632 Jardim Botânico - CEP: 80210-170. Curitiba, PR, Brazil. E-mail: leticiasakai@ gmail.com 


\section{Introduction}

The physical health of the elderly may be compromised considering that aging is often marked by gradual decline of various physiological systems, multimorbities and dependencies that contribute to the loss of autonomy and independence. This becomes even more worrisome when the elderly is in the condition of pre-frailty or physical frailty ${ }^{(1)}$.

Physical frailty is defined as "a medical syndrome with multiple causes and contributions/determinants that is characterized by decreased strength, endurance and physiological function that increases the vulnerability of the individual and leads to greater dependence and/or death"(1:392). The phenotype of this syndrome consists of five components: unintentional weight loss, self-report of fatigue/exhaustion, reduced hand grip strength, reduced physical activities and reduction of gait speed ${ }^{(2)}$.

An international study of 7,439 elderly people (aged $\geq 65$ years) indicated a significant pre-frailty index in the elderly, corresponding to $45.0 \%$ of the sample $^{(3)}$. This percentage is even higher in the national context, as observed in a survey of 958 elderly people, of whom 522 (55.4\%) were classified as pre-frail ${ }^{(4)}$.

Identifying pre-frailty is essential for health care planning, because this condition is amenable to reversal. Furthermore, there is a need to improve the scenarios of the various institutions and services that are useful for the elderly, so that they be able to meet the particularities of this age group. Among the services is the institution responsible for the acquisition or renewal of the national driver's license.

Statistical data show a significant number of elderly drivers of motor vehicles. In 2013, according to a survey conducted by the Transit Department of Paraná, there were 219,439 drivers over 65 who were active and driving. This share of the elderly represents $4.7 \%$ of the 4.5 million drivers registered in Paraná and is estimated to rise in the next years ${ }^{(5)}$. In 2015, in Espírito Santo, there were 1,328,344 drivers, of which $163,513(12.3 \%)$ were over $60^{(6)}$. In the same year, in the State of Rio de Janeiro, the estimates were of $5,469,196$ drivers, of which 564,332 (10.3\%) were elderly ( $\geq 60$ years $)^{(7)}$.

Driving a motor vehicle is important for the elderly, as it allows independent ${ }^{(8)}$ mobility and has a positive impact on their quality of life. However, driving a car can become an increasingly difficult activity with advancing years, due to the aging process and declines in visual, motor and cognitive functions. This contributes to reducing the safety of the elderly driver in the traffic, besides endangering other drivers and pedestrians.

In view of the significant number of elderly drivers of motor vehicles, the high incidence of pre-frailty in Brazilian elderly and the lack of national scientific knowledge on the subject, it is important to screen for physical frailty among this particular population. The physical fragility phenotype is one of the instruments that can provide an evaluation of the elderly segment of the population and, consequently, contribute to a safer driving.

Therefore, the following question was set for this research: what is the association between the condition of physical pre-frailty in the elderly and the final results of the driver license test for motor vehicles? The objective is to investigate the association between the condition of physical pre-frailty in the elderly and the final results of the driver license test for motor vehicles.

\section{Methods}

This is a cross-sectional study carried out with elderly people ( $\geq 60$ years old) who underwent physical and mental evaluation for driver license test. The study site comprised 54 evaluation clinics in the city of Curitiba, PR, Brazil, in the period from August 2015 to March 2016.

The selection of clinics occurred by a simple draw. The clinics were classified as C1 to C54 and were evaluated in this sequence to identify the linkage of clinics participating in the study, according to the 
inclusion criteria: to be accredited to perform physical and mental and/or psychological evaluationand, and to have a proper space to perform the tests.

Due to the lack of quantitative data on the number of elderly patients received in each clinic and the way of distribution of the elderly by the traffic institution, a standard number of 35 elderly people was evaluated in each of the 11 clinics drawn until the end of the sampling period.

The following inclusion criteria of participants were chosen: age $\geq 60$ years; presenting cognitive ability assessed by the Mini-Mental State Examination, according to the schooling: 13 points for individuals without schooling, 18 points for low and medium schooling and 26 points for high schooling ${ }^{(9)}$. The exclusion criteria were: to present diseases, problems and/or physical symptoms that, for any reason, could prevent the application of the questionnaires and the tests.

Four hundred and nineteen elderly people were approached in the sample period, 43 of whom refused to participate. Among the elderly who agreed to participate in the study, 29 were excluded because they did not reach the required score in the Mini-Mental State Examation. Thus, the final sample consisted of 347 participants.

Data collection was performed using a structured questionnaire, a physical frailty syndrome evaluation and data was searched to identify the final result of the physical and mental evaluation in the National Driver Register. The structured questionnaire addressed sociodemographic and driving-related issues: age, sex, marital status, schooling, type of vehicle (manual or automatic transmission), difficulty to push the pedals, hold the steering and handling the gearshift.

To evaluate physical frailty, the five components of the phenotype ${ }^{(2)}$ : unintentional weight loss; gait speed; hand grip strength; self-reported fatigue/ exhaustion and level of physical activity. Unintentional weight loss was assessed according to self-report of weight loss in the last 12 months. The elderly who reported loss equal to or greater than $4.5 \mathrm{~kg}$ of body weight were considered frail.

Gait speed was evaluated by the average time in seconds that the elderly would take to travel three times, in a usual speed and in a flat floor, a distance of 4.6 meters. The start and end distance of 4.6 meters were marked by a signaling rope. Values were adjusted for median height, according to sex. The elderly with values in the lowest quintile were considered frail for this component.

Hand grip strength was measured using a Jamar dynamometer (Lafayette Instruments, Lafayette, Indiana, United States) placed in the dominant hand of the elderly, in three attempts, with a one-minute interval between them. The elderly whose average of the three measures was in the lowest quintile, adjusted for sex and body mass index, were considered frail.

Fatigue/exhaustion was evaluated according to self-report in the response to items 7 and 20 of the Depression Scale ${ }^{(10)}$ : In the last week, say how often (A) you felt that everything you did was an struggle? And (B) you felt that you cannot continue doing your things? The possible answers were: 0 - rarely or never ( $<1$ day), 1 - part or small part of the time (1-2 days), 2 - good of the time (3-4 days) and 3 - most of the time ( $>4$ days). The elderly who answered "2" or " 3 " for any of these questions was considered frail for this component.

The level of physical activity was assessed through the Minnesota Leisure Activity Questionnai$\mathrm{re}^{(11)}$, validated for Brazilian elderly. The questionnaire makes it possible to measure the caloric expenditure by means of self-reported involvement in different physical activities in the last year. After adjusting for sex, the values that were in the lowest quintile were considered frail for this component.

From these five components, the elderly frail for three or more of these characteristics were considered overall frail; those who were frail in one or two criteria were classified as overall pre-frail (focus of the present study); and those who did not present frailty in any of the components were considered non-frail, according to the theoretical and methodological 
basis of the study ${ }^{(2)}$.

The last stage of the study consisted in a search in the National Driver Register with the aim of identifying the final result of the physical and mental evaluation, which has the categories: "able", "able with restrictions", "temporarily unable" and "unable"(12). When the result is "able with restrictions", the system specifies the restrictions that the candidate presented.

The data were analyzed in the Statistical Package for Social Sciences version 20.0. Non-parametric tests of association between variables (chi-square) were used in the statistical analyses; $p$-values $\leq 0.05$ were considered statistically significant.

The study complied with the formal requirements contained in the national and international regulatory standards for research involving human beings.

\section{Results}

Of the 347 elderly participants, four (1.2\%) were considered frail, $163(47.0 \%)$ pre-frail and 180 (51.8\%) non-frail. Among the pre-frail elderly, the mean age was $69.2( \pm 7.31)$ years, with a minimum of 60 and a maximum of 90 years. There was a predominance of male elderly ( $\mathrm{n}=116 ; 71.2 \%)$, married $(n=106 ; 65.0 \%)$, followed by widowers $(n=24$, $14.7 \%)$, divorced/separated/judiciously separated $(n=16 ; 9.8 \%)$, single $(n=13,8.0 \%)$ and living with a partner $(\mathrm{n}=4,2.5 \%)$.

The level of education with the highest frequency was higher education $(n=53,32.5 \%)$, followed by complete secondary education $(n=28 ; 17.2 \%)$, complete primary school $(n=22 ; 13.5 \%)$, incomplete primary school $(\mathrm{n}=16 ; 9.8 \%)$, complete elementary school $(n=14 ; 8.6 \%)$, incomplete elementary school $(n=14 ; 8.6 \%)$, incomplete higher education $(n=8$; $4.9 \%)$, incomplete secondary education $(n=5 ; 3.1 \%)$ and those who read and write $(n=3 ; 1.8 \%)$.

Regarding the components of frailty, there was a prevalence of reduced hand grip strength in 71
(43.6\%) elderly, followed by reduced level of physical activity $(n=65,39.9 \%)$ and gait speed $(n=62,38.0 \%)$. Unintentional weight loss was identified in only 12 (7.4\%) elderly, and self-report of fatigue and exhaustion was not present in the studied population.

The driving-related variables showed a predominance of elderly drivers of manual vehicles $(n=122$, $74.9 \%)$, followed by automatic vehicles ( $n=33,20.3 \%)$, manual and automatic vehicles $(n=7,4.3 \%)$ and elderly who did not have a car ( $n=1,0.6 \%)$. The majority of the elderly had no difficulty in pushing the pedals ( $n=160,98.2 \%$ ), but three $(1.8 \%)$ reported to have this difficulty. None of the elderly reported difficulties with the steering $(n=163,100.0 \%)$ or with gearshift ( $\mathrm{n}=163,100.0 \%)$.

Among the 163 pre-frail elderly, 37 (22.7\%) were considered able, 115 (70.6\%) able with restriction and 11 (6.7\%) temporarily unable to drive, according to the final results of the driver license test.

Table 1 - Distribution of restrictions applied to the final result of the driver license test for the pre-frail elderly

\begin{tabular}{lc}
\hline Driver license restriction & n (\%) \\
\hline Corrective lenses & $82(50.3)$ \\
Change to lower category & $54(33.1)$ \\
Reduced expiration time & $17(4.8)$ \\
Altered clinical condition & $11(6.7)$ \\
Use of hearing aid & $2(1.2)$ \\
Not allowed to drive on fast roads & $1(0.6)$ \\
Need for special examination & $1(0.6)$ \\
Monocular vision & $1(0.6)$ \\
Not allowed to drive on highway after sunset & $1(0.6)$ \\
\hline $\begin{array}{l}\text { Note: the sum of the restrictions exceeds the number of pre-frail elderly indi- } \\
\text { viduals because a same person may present one or more restrictions }\end{array}$
\end{tabular}

Table 1 shows the types of restrictions of the pre-frail elderly in the final result of the driver license test. There was a predominance of mandatory use of corrective lenses ( $n=82 ; 50.3 \%)$, followed by change to lower category $(n=54 ; 33.1 \%)$. 
Table 2 - Association between pre-frailty and the driver test results for the pre-frail elderly

\begin{tabular}{lccc}
\hline \multirow{2}{*}{ Driver license test result } & \multicolumn{3}{c}{ Physical pre-frailty } \\
\cline { 2 - 4 } & $\begin{array}{c}\text { Yes } \\
\text { n (\%) }\end{array}$ & $\begin{array}{c}\text { No* } \\
\text { n (\%) }\end{array}$ & p $\dagger$ \\
\hline Able & $37(22.7)$ & $48(26.0)$ & \\
Able with restriction & $115(70.6)$ & $123(67.0)$ & 0.744 \\
Temporarily unable & $11(6.7)$ & $13(7.0)$ & \\
Total & $163(100.0)$ & $184(100.0)$ & \\
*For the "no" category of the variable pre-frailty, the frail elderly (n=4) were \\
grouped with the non-frail elderly (n= 180); $\dagger$ Chi-square test; $\mathrm{p} \leq 0.05$
\end{tabular}

The results of the driver license test show a predominance of pre-frail elderly ( $\mathrm{n}=115,70.6 \%)$. There was no significant statistical association between pre-frailty and the result of the elderly's driver license test (Table 2).

\section{Discussion}

The limitations of the study to be noted are related to the method, which does not allow the establishment of cause and effect relationships, and the self-reported type of questions that make up the evaluation of the phenotype of fragility. The results of the hand grip strength assessment collected by the transit institution and by the researchers were different: the first had pre-established cut-off points for adults and older adults that indicate reduced hand grip strength and uses a less accurate dynamometer; the criterion used in the present study, on the other hand considers the values of hand grip strength the values reduced when these lay in the lowest quintile of the sample studied, and uses a more sensitive dynamometer.

Among the elderly who underwent physical and mental evaluation, men predominated. The prevalence of males is linked to the occupation of professional drivers; few women practice occupations as drivers. Researchers evaluated 172 elderly to investigate the association between physical frailty and sociodemographic and clinical characteristics of elderly undergoing the driver license test, and they found predominance of males among participants $(n=120$; $70.6 \%)^{(13)}$.

The pre-frail condition $(\mathrm{n}=163 ; 47.0 \%)$ was similar to that found in international ${ }^{(3,14)}$ and nation$\mathrm{al}^{(15-16)}$ surveys assessing this phenotype ${ }^{(2)}$. In North America, the percentage of pre-frail elderly was around $45.5 \%{ }^{(3)}$, and in the Asian continent, $47.3 \%{ }^{(14)}$. The Brazilian study with 433 elderly people that validated the instrument by self-reported frailty syndrome assessment found $45.9 \%$ of pre-fragile elder$1 y^{(16)}$. In a study that identified the profile of frailty and its associated factors in 139 elderly people enrolled in a Family Health Unit, the prevalence was even higher: $61.8 \%{ }^{(15)}$.

Pre-frail elderly often make up the highest percentage of the sample in studies ${ }^{(2-4,14)}$ regardless of the site investigated. This endorses the importance of interventions aimed at pre-frailty, a condition with greater preventive potential, for anticipating the dependence and the clinical manifestations typical of the syndrome ${ }^{(1)}$.

Difficulty to push pedals, reduced hand grip strength, level of physical activity and gait speed were found among the pre-frail older people able to drive. It is believed that these aspects may represent risk factors for safe driving. It is important to intervene in the pre-frail stage by considering the positive consequences of maintaining a safe driver as long as possible $^{(13)}$.

The need to track pre-frail elderly during the physical and mental evaluation at the driver license test is very pertinent, since the evolution of this condition can be rapid and compromise the safe driving. The pre-frail condition is susceptible to interventions, among them the use of vitamin $\mathrm{D}$, caloric and protein supplementation, the practice of physical activity and the reduction of polypharmacy ${ }^{(1)}$.

When considering the predominance of elderly people using a manual-shift car, hand gripping strength is of the utmost importance. The use of ad- 
equate force allows for safer shifts and maneuvers with the steering wheel of the vehicle. Analyses based on data from the Sarcopenia Project concluded that increases in hand grip strength may have positive effects on the physical fitness of the elderly ${ }^{(17)}$.

The reduction of the level of physical activity of pre-frail elderly was the second most prevalent component in the study. A similar result was found in a research that investigated the association between hand grip strength and physical activity in the elderly in the condition of physical frailty. The decrease in physical activity was identified in 73 (37.4\%) pre-frail primary health care users ${ }^{(18)}$.

In order to examine exercise interventions to manage frailty in the elderly, researchers suggested in a review study that physical training programs aimed at vulnerable elderly could improve their physical condition. The review did not show the best exercise program but considered its practice to be relevant and a positive influence on the process of frailty ${ }^{(19)}$.

The third most frequent component was the reduced gait speed $(n=62,38.0 \%)$. This is an important marker to be investigated. It evaluates the physical and functional performance of the elderly and is indicated as a criterion for the identification of sarcopenia ${ }^{(20)}$. Reduced gait speed may be detrimental to driving vehicles, as it may cause difficulty to press the pedals with the lower limbs.

The pre-frail condition was frequent but not significantly associated $(p=0.744)$ with the final results of the physical and mental evaluation of the elderly. This is worrisome when considering the expressive number of pre-frail elderly who were considered to be able to drive vehicles, despite the restriction.

Assessing the physical condition of elderly drivers of vehicles is imperative because they may present weaknesses in manual grip strength or gait speed. These, in turn, may pose some risks for car driving, not only to the elderly themselves but also to the general population. It should be emphasized that the unit responsible for controlling traffic through license tests only evaluates the manual grip strength using a less accurate dynamometer (10 Kgf graduation).

Although most of the elderly were approved for driving with restrictions and received the National Driver's License, we emphasized that these are not strictly disabling physical restrictions. This might explain the absence of the relationship between the physical frailty in the elderly and the final result of the driver license test. There is a significant lack of studies in the current literature addressing pre-fragility and driving, and this restricted the discussions of the present results.

The study is novel for gerontological nursing, pointing to the need for further research on the subject, and offers subsidies for a safer traffic, based on more complete evaluations that investigate the particularities of elderly drivers. The applicability of the findings includes the identification of pre-frail individuals and the help in the creation of programs to subsidize interventions to revert the syndrome of frailty among elderly drivers of vehicles.

\section{Conclusion}

Pre-frailty was frequent among the elderly undergoing the physical and mental evaluation for the driver license test, but there was no significant association between the pre-frail condition and the result of the test. From the high number of pre-frail elderly, the majority was approved with restrictions in the driver license test and, among the components of frailty, reduced hand grip strength, reduced level of physical activity and reduced gait speed prevailed.

\section{Acknowledgements}

To the Fundação Araucária de Apoio ao Desenvolvimento Científico e Tecnológico do Paraná, for the financial support. Process no45784. 


\section{Collaborations}

Lenardt MH, Betiolli S, Sakai LM, Carneiro NHK, Binotto MA and Moraes DC contributed to the project design, data analysis and interpretation, article writing, critical review of the intellectual content and final approval of the version to be published.

\section{References}

1. Morley J, Vellas B, Avellan VKG, Anker S, Bauer J, Bernabei R, et al. Frailty consensus: a call to action. J Am Med Dir Assoc. 2013; 14(6):392-7. doi: http://dx.doi.org/10.1016/j.jamda.2013.03.022

2. Fried L, Tangen C, Walston J, Newman A, Hirsch C, Gottdiener J, Seeman T, et al. Frailty in older adults: evidence for a phenotype. J Gerontol A Med Sci Med Sci. 2001; 56(3):46-56

3. Bandeen-Roche K, Seplaki C, Huang J, Buta B, Kalyani R, Veradhan R, et al. Frailty in older adults: a nationally representative profile in the United States. J Gerontol A Biol Sci Med Sci. 2015; 70(11):1427-34. doi: http://dx.doi.org/10.1093/ gerona/glv133

4. Pegorari MS, Tavares DMDS. Factors associated with the frailty syndrome in elderly individuals living in the urban area. Rev Latino-Am Enfermagem. 2014; 22(5):874-82. doi: http:// dx.doi.org/10.1590/0104-1169.0213.2493

5. Rosa D. Paraná tem 219 mil motoristas com mais de 65 anos de idade. Departamento de Trânsito do Paraná [Internet]. 2012 [citado 2016 Out 17]. Disponível em: http://www.detran.pr.gov.br/ modules/noticias/article.php?storyid $=689$

6. Departamento de Trânsito do Espírito Santo. Relatório Anual de Estatística de Trânsito - 2015 [Internet]. 2015 [citado 2011 jun 27]. Disponível em: http://www.detran.es.gov.br/default.asp

7. Departamento de Trânsito do Rio de Janeiro. Anuário Estatístico 2015 [Internet]. 2015 [citado 2011 jun 27]. Disponível em: http://www.detran. rj.gov.br/_include/geral/anuario_estatistico_ detran_rj_2015.pdf
8. Karthaus M, Falkenstein, M. Funcional changes and driving performace in older drivers: assessment and interventions. Geriatrics. 2016; 12(1):2-18. doi: http://dx.doi.org/10.3390/ geriatrics1020012

9. Bertolucci PHF, Brucki SMD, Campacci SR, Juliano Y. The Mini-Mental State Examination in an outpatient population: influence of literacy. Arq Neuropsiquiatr. 1994; 52(1):1-7. doi: http://dx.doi. org/10.1590/S0004-282X1994000100001

10. Radloff LS. The CES-D scale: a self-report depression scale for research in the general population. Appl Psychol Meas. 1977; 1(3):385401.

11. Taylor HL, Jacobs Jr DR, Schucker B, Knudsen J, Leon AS, Debacker G. A questionnaire for the assessment of leisure-time physical activities. J Chronic Dis. 1978; 31(12):745-755. doi: http:// dx.doi.org/10.1016/0021-9681(78)90058-9

12. Conselho Nacional de Trânsito (BR). Código de Trânsito Brasileiro. Resolução n517 de 29 de janeiro de 2015: altera a Resolução CONTRAN n ${ }^{\circ}$ 425, de 27 de novembro de 2012, que dispões sobre o exame de aptidão física e mental, a avaliação psicológica e o credenciamento das entidades públicas e privadas que tratam o art. 147 e $\S \S 1^{\circ}$ o a 4ํㅡ, e o art. 148 do Código de Trânsito Brasileiro. Brasília: Conselho Nacional de Trânsito; 2015.

13. Lenardt MH, Cechinel C, Binoto MA, Carneiro NHK, Lourenço TM. Relationship between physical fragility and socio-demographical and clinical factors of elderly performing driving license testing. Esc Anna Nery. 2016; 20(4):1-9. doi: http://dx.doi.org/10.5935/1414-8145.20160097

14. Çakmur H. Frailty among elderly adults in a rural area of Turkey. Med Sci Monit. 2015; 21:1232-42. doi: http://dx.doi.org/10.12659/MSM.893400

15. Santos PHS, Fernandes MH, Casotti CA, Coqueiro RDS, Carneiro JAO. Perfil de fragilidade e fatores associados em idosos cadastrados em uma Unidade de Saúde da Família. Cienc Saúde Coletiva. 2015; 20(6):1917-24. doi: http://dx.doi. org/10.1590/1413-81232015206.17232014 
16. Nunes D, Duarte Y, Santos J, Lebrão M. Screening for frailty in older adults using a self-reported instrument. Rev Saúde Pública. 2015; 49(2). doi: 10.1590/S0034-8910.2015049005516

17. Alley DE, Shardell MD, Peters KW, McLean RR, Dam TTL, Kenny AM, et al. Grip strength cutpoints for the identification of clinically relevant weakness. J Gerontol A Biol Sci Med Sci. 2014; 69(5):559-66. doi: http://dx.doi.org/10.1093/gerona/glu011

18. Lenardt MH, Carneiro NHK, Binotto MA, Setoguchi LS, Cechinel C. The relationship between physical frailty and sociodemographic and clinical characteristics of elderly. Esc Anna Nery. 2015; 19(4):585-92. doi: http://dx.doi. org/10.5935/1414-8145.20150078
19. Labra DC, Guimaraes-Pinheiro C, Maseda A, Lorenzo T, Millán-Selenti JC. Effects of physical exercise interventions in frail older adults: a systematic review of randomized controlled trials. BMC Geriatr. 2015; 15:154. doi: http://dx.doi. org/10.1186/s12877-015-0155-4

20. Cruz-Jentoft A, Landi F, Schneider MS, Zunga C, Arai $\mathrm{H}$, Boire $\mathrm{Y}$, et al. Prevalence of and interventions for sarcopenia in ageing adults: A systematic review. Report of the International Sarcopenia Initiative (EWGSOP and IWGS). Age Ageing. 2014; 43(6):748-59. doi: http://dx.doi.org/10.1093/ ageing/afu115 